\title{
Reptilian Diversity and Distributions in the Doda District of Jammu and Kashmir, India
}

\author{
Amit Manhas ${ }^{1}$, Rajni Raina ${ }^{2}$, and Ashwani Wanganeo ${ }^{1}$
}

${ }^{1}$ Department of Environmental Sciences and Limnology, Barkatullah University, Bhopal, Madhya Pradesh, India (amitmanhas1986@gmail.com) ${ }^{2}$ Department of Zoology, Government Science and Commerce College (Benazir), Bhopal, Madhya Pradesh, India

$\mathrm{R}$ eptiles are important components of Earth's ecosystems; consequently, documenting current distributions is critical in light of changing land-use patterns and climatic conditions, the resultant declines in habitat abundance and quality, and the increasing risk of extinction facing many species (Gibbons et al. 2000; Stuart et al. 2008). Of the approximately 10,700 species of reptiles (Uetz et al. 2018), 518 species (34 turtles, 3 crocodilians, 279 snakes, and 202 lizards) in 28 families occur in India (Aengals et al. 2011). Herein we present the results of a reptilian diversity survey we conducted in the Doda District of Jammu and Kashmir, India from March to mid-June in 2014 and 2015. The Doda District is in the eastern part of the Jammu Region $\left(33^{\circ} 08^{\prime} \mathrm{N}, 75^{\circ} 3^{\prime} \mathrm{E}\right)$ in the outer Himalayan Range and has an average elevation of 1,107 $\mathrm{m}$ asl.

Previous work in the state (using current taxonomy instead of the historical names used in the various reports) began with Fenton (1910), who recorded vernacular names for snakes that included the Himalayan Pitviper (Gloydius himalayanus), Levantine Viper (Macrovipera lebetina), and the Oriental Ratsnake (Ptyas mucosa). Das (1966) indicated that the reptiles of Kashmir were representative of Palearctic elements. Sharma and Sharma (1975) recorded 18 species of snakes from the state. Duda and Sahi (1977) listed four species of turtles (Indian Roofed Turtle, Pangshura tecta; Brown Roofed Turtle, Pangshura smithii; Indian Flap-shelled Turtle, Lissemys punctata; Ganges Soft-shelled Turtle, Nilssonia gangetica) that had not been reported previously from Jammu (the record of P. smithii was the first from northwestern India). Duda and Sahi (1978) described a new gekkonid species (Himalayan Bent-toed Gecko, Cyrtodactylus himalayanus) from the Doda District.

The first extensive herpetological survey by Sahi (1979) listed seven species of turtles, 23 species of lizards, and 35 species of snakes from the state. Sahi and Duda (1982) described six little-known species of lizards, of which the Asian Snake-eyed Skink (Ablepharus pannonicus) was new to India and the Fan-throated Lizard (Sitana ponticeriana), the Punjab Snake-eyed Lacerta (Ophisops jerdonii), and the Indian Fringe-fingered Lizard (Acanthodactylus cantoris) were recorded for the first time from the state. Sahi and Duda
(1985) presented a checklist and keys to amphibians and reptiles of Jammu and Kashmir, and in 1986 they described the affinities and distributions of the reptiles, noting that three agamid species in the genus Laudakia were of Palearctic origins, whereas two species of geckos in the genus Hemidactylus and an agamid in the genus Calotes were Oriental species. Verma and Sahi (1995) studied the Indian Monitor (Varanus bengalensis) and concluded that it warranted protection in the state.

Ali et al. (2004) indicated that venomous snake-bite cases were common during the summer, reporting 360 Saw-scaled Viper (Echis carinatus) bites, as a result of which 62 patients developed acute renal failure within 24 hours to two weeks of envenomation. Sharma and Kour (2005) described the karyology of four species of snakes (Common Sand Boa, Eryx conicus; Indian Cobra, Naja naja; Russell's Viper, Daboia russellii; Saw-scaled Viper, Echis carinatus). Chowdhary (2010) recorded nine species in five families of squamate reptiles from the Rajouri District. Manhas et al. (2015) presented the first record of the Himalayan Wolfsnake (Lycodon mackinnoni) from the Doda Region, and Manhas et al. (2016) listed 16 species of reptiles in nine families from the city of Jammu. Manhas et al. (2018a) presented observations of the high-elevation Agror Agama (Laudakia agrorenisis) and Manhas et al. (2018b) recorded new distributional records of the Himalayan Bent-toed Gecko (Cyrtodactylus himalayanus) from the Doda region.

A critical assessment of the above review clearly indicates that not much is known about the reptilian fauna of the Doda region of J and K State, India. Consequently, creating a comprehensive list of reptiles and their distributions was a worthwhile and necessary endeavor.

\section{Methods}

Because of the area's mountainous nature, we divided the study area into five surveying stations (Fig. 1): (1) Nai-Bhallara (3305'20.69' 'N, 7542'30.24"E; elev. 1,693-2,328 m), (2) Village Chagsoo $\left(33^{\circ} 07^{\prime} 33.27^{\prime \prime} \mathrm{N}, 75^{\circ} 40^{\prime} 11.50^{\prime \prime E}\right.$; elev. 1,097--2,269 m), (3) Village Zazinda (33''34.48"N, 75³8'19.74"E; elev. 1,566-2,306 m), (4) Bhaderwah City $\left(32^{\circ} 58^{\prime} 47.89^{\prime \prime} \mathrm{N}, 75^{\circ} 42^{\prime} 57.27^{\prime \prime} \mathrm{E}\right.$, elev. 1,514- 


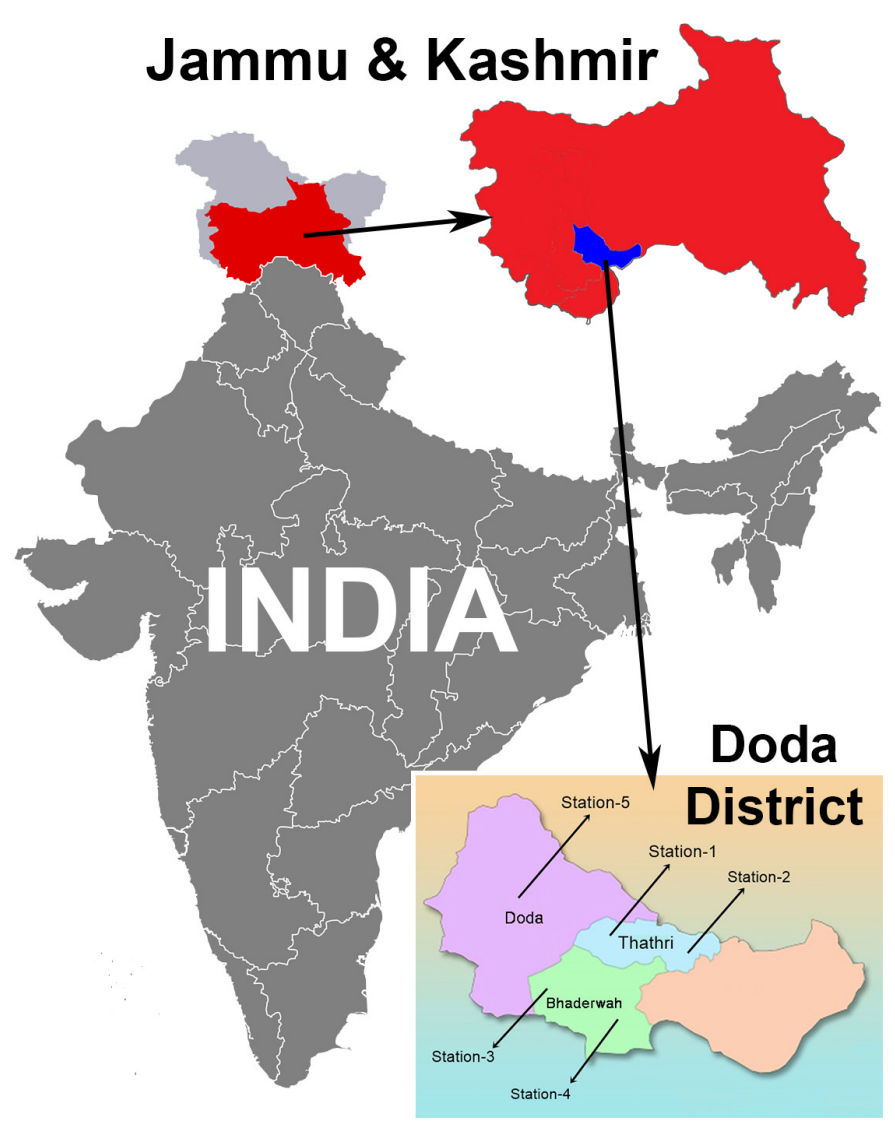

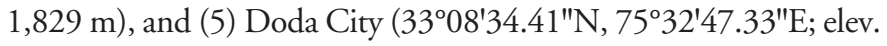
975-1,282 $\mathrm{m}$ ). Stations 1 and 2 were in the Tehsil (= administrative district) Thathri, stations 3 and 4 in the Tehsil Bhaderwah, and station 5 in the Tehsil Doda.

We employed the visual encounter method (Campbell and Christman 1982) by searching each site on foot in all four cardinal directions from the starting points listed above, covering an area with a radius of 5-8 km. Each site was surveyed for four successive days from 1000-1800 h in March through mid-June in 2014 and 2015. In addition to the regular surveys, we adventitiously visited sites. We caught animals by hand, used snake-hooks to pin larger snakes, turned surface cover objects, noted dead animals (e.g., roadkills) and shed skins, and used binoculars for observations at a distance. We used a Sony DSC-HX 300 camera to document encounters and recorded GPS coordinates for each animal. Ambient temperatures were taken with a mercury thermometer in the shade and sheltered from wind.

Care was taken not to unduly disturb or dislocate animals. If we disturbed any hiding places during collection, we reconstructed them as best we could. If animals were collected, we immediately released them after noting relevant features and taking morphometric measurements.

We identified animals using descriptions in Smith (1935, 1945), Sahi (1979), Daniel (2002), Whitaker and Captain (2004), Whitaker (2006), Khaire (2010, 2014), and Indiansnakes.org. Dr.
R. Aengals, Zoological Survey of India, confirmed the identity of some animals from photographs.

\section{Results and Discussion}

We recorded 17 species of squamate reptiles (seven species of lizards and ten species of snakes). Details for each species are given below. The only species that has been assessed for the IUCN Red List (IUCN 2018) is the Sikkim Keelback (Herpetoreas sieboldii), which was assessed as Data Deficient "as distributional information is uncertain and there are no data on its abundance, habitat preferences, or threats. Further research and monitoring is needed before a more accurate assessment can be carried out" (Khan and Papenfuss 2016).

Himalyan Bent-toed Gecko, Cyrtodactylus himalayanus (Duda and Sahi 1978) (Gekkonidae) (Fig. 2) - We recorded this species from stations 1-3 at elevations of 1,743-2,157 $\mathrm{m}$ asl and ambient temperatures of $15-19^{\circ} \mathrm{C}$ in April (2014), May (2015), and June (2015). Sahi (1979) reported the presence of $C$. himalayanus in a house in Kishtwar $\left(75.7^{\circ} \mathrm{E} ; 33^{\circ} \mathrm{N}\right)$ at an elevation of $1,700 \mathrm{~m}$ asl in May and October 1975.

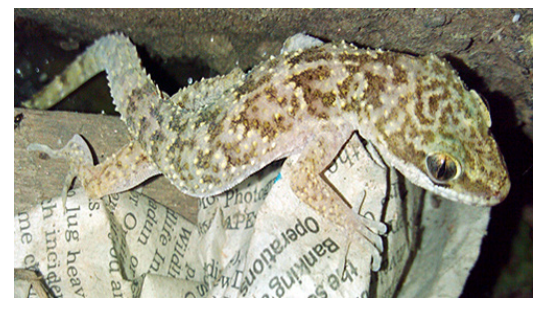

Indian Garden Lizard, Calotes versicolor (Daudin 1802) (Agamidae) (Fig. 3) - We recorded this species from stations 1-3 at elevations of 1,743-2,073 $\mathrm{m}$ asl and ambient temperatures of $10-22{ }^{\circ} \mathrm{C}$ in April through June in 2014 and 2015. All were in bushes or trees where they were well-camouflaged. Sahi (1979) reported the presence of C. versicolor in Jammu in June 1976 and April and September 1977, in Udhampur in July 1976, in Kathua in September 1976, in Mansar in April 1975, in Rajouri in May 1977, in Poonch in May 1977, in Akhnoor in June 1977, and in R.S. Pura in September 1977. Chowdhary (2010) noted that the species was in bushes, hedges, and trees where it remained camouflaged and inactive, but moved to bushy cover when threatened. $\mathrm{He}$ reported that the species was not observed at elevations above 1,000 $\mathrm{m}$ asl in the Rajouri District of Jammu and Kashmir.

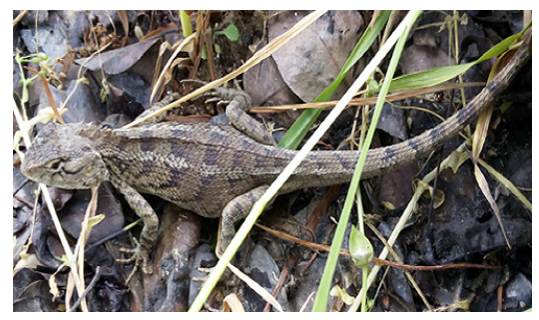


Indian Garden Lizard, Calotes sp. (Agamidae) (Fig. 4) - We recorded this species from station 5 at an elevation of 1,156 m.asl and an ambient temperature of $18{ }^{\circ} \mathrm{C}$ in May 2014. This individual was quite different in appearance than typical male C. versicolor from the area. We suspect it is another species in the C. versicolor complex.

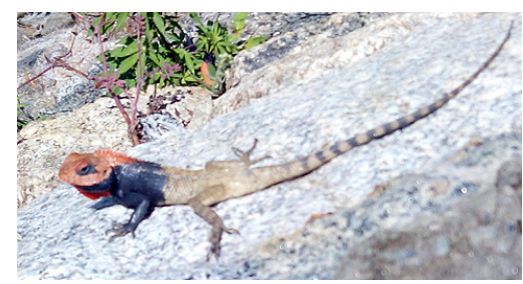

Agror Agama, Laudakia agrorensis (Stoliczka 1872) (Agamidae) (Fig. 5) - We recorded this species from stations 1-3 at elevations of 1,216-2,198 $\mathrm{m}$ asl and ambient temperatures of 19-24 ${ }^{\circ} \mathrm{C}$ in May through mid-June in 2014 and 2015. Smith (1935) reported the presence of L. agrorensis in Punjab (Agror Valley) and Kashmir (Jhelum Valley), and Sahi (1979) documented its presence in Nandani, Mansar Village, and Ramban in April 1976, June 1977, and July 1977, respectively.

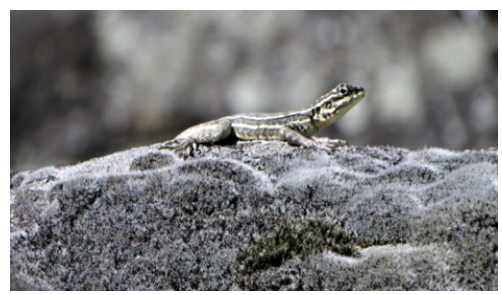

Kashmir Rock Agama, Laudakia tuberculata (Gray 1827) (Agamidae) (Fig. 6) - We recorded this species from stations 1-5 at elevations of 975-2,047 $\mathrm{m}$ asl and ambient temperatures of 15-33 ${ }^{\circ} \mathrm{C}$ in March through June in 2014 and 2015. Like Singh and Banyal (2014), we observed it basking on rocks on sunny days, but retreating into crevices or beneath rocks at dawn and dusk and on cloudy days. We also saw it feeding on both insects and leaves of herbaceous plants. Sahi and Duda (1986) reported the presence of L. tuberculata in Bhaderwah and Kishtwar. Chowdhary (2010) recorded the species from the Rajouri District at elevations to 2,200 $\mathrm{m}$ asl.

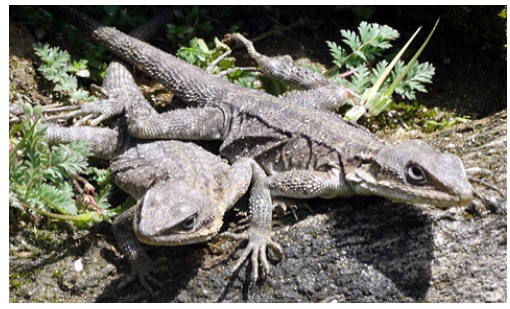

Himalayan Agama, Paralaudakia himalayana (Steindachner 1867) (Agamidae) (Fig. 7) — We recorded this species from station 5 at an elevation of $1,151 \mathrm{~m}$ asl and an ambient temperature of $25^{\circ} \mathrm{C}$ in June 2015. Sahi (1979) reported the presence of $P$. himalayana from Dras in May 1976, Kargil in May 1976, and Leh in June 1977 , noting that it is a high-elevation adapted Palearctic species.

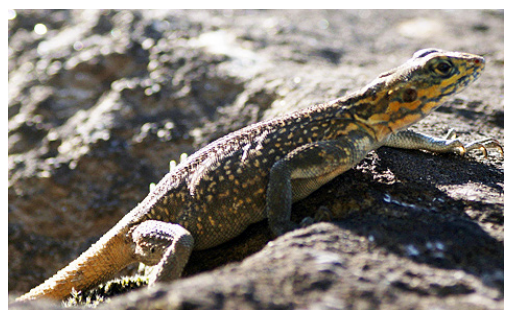

Himalayan Ground Skink, Asymblepharus himalayanus (Günther 1864) (Sphenomorphidae) (Fig. 8) - We recorded this species from stations 1-5 at elevations of 1,125-2,291 $\mathrm{m}$ asl and ambient temperatures of $15-30^{\circ} \mathrm{C}$ in March through June in 2014 and 2015, always during the day and most frequently at the lower end of the temperature range. Sahi (1979) reported the presence of A. himalayanus from Sonamarg near the Tajawas Glacier $(2,743 \mathrm{~m}$ asl) and from Leh and Kargil at an elevation of 3,352 m asl, noting that these lizards were diurnal and active at low temperatures.

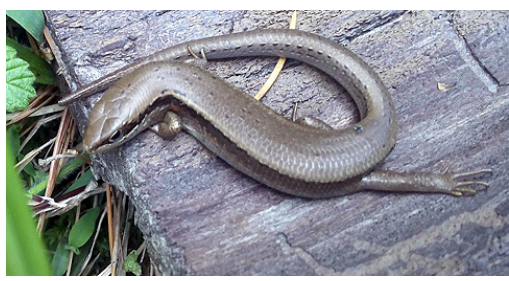

Himalayan Keelback, Herpetoreas platyceps (Blyth 1854) (Natricidae) (Fig. 9) - We recorded this species from stations 1 and 3 at elevations of 1,830-2,175 $\mathrm{m}$ asl and ambient temperatures of $18-25^{\circ} \mathrm{C}$ in May 2015 and June in 2014, respectively. Sahi (1979) reported the presence of $H$. platyceps from Poonch in June 1976 and July 1977 and from Srinagar in July and August 1977.

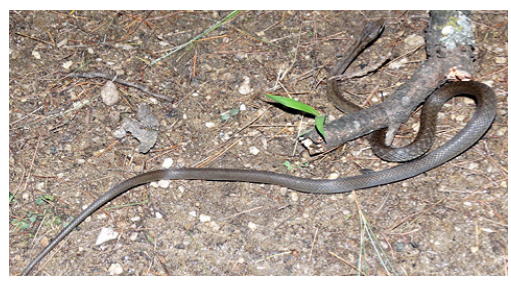

Sikkim Keelback, Herpetoreas sieboldii Günther 1860 (Natricidae) (Fig. 10) - We recorded this species from station 1 at an elevation of 1,851 $\mathrm{m}$ asl and an ambient temperature of 20 ${ }^{\circ} \mathrm{C}$ in May 2015. Khan and Papenfuss (2010) reported the presence of $H$. sieboldii from the Tung-gyi Region of northern Myanmar, Ghora Gali in Pakistan, Nepal, and in the Alpine Punjab of India. Agarwal et al. (2010) reported it from Bompu, Arunachal Pradesh, India at an elevation of $1,945 \mathrm{~m}$ asl. This is a new record for the 
region; pattern and meristic characters match published descriptions of the species.

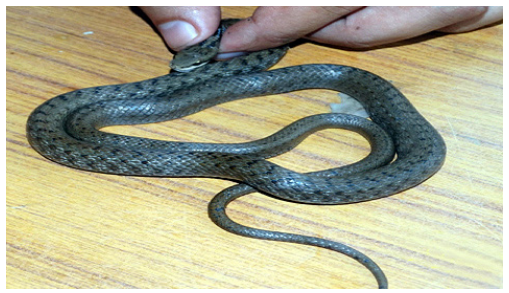

Himalayan Wolfsnake, Lycodon mackinnoni Wall 1906 (Colubridae) (Fig. 11) - We recorded this species from station 1 at elevations of 1,699-1,824 $\mathrm{m}$ asl and ambient temperatures of $14-19{ }^{\circ} \mathrm{C}$ in June 2014 and May 2015. These snakes were near human settlements and in agricultural fields. Wall (1906) reported the presence of L. mackinnoni from Mussoorie at an elevation of about 1,860 m asl. Smith (1943) recorded it from the western Himalayas (viz., Mussoorie, Alomar, and Muktesar near Nainital).

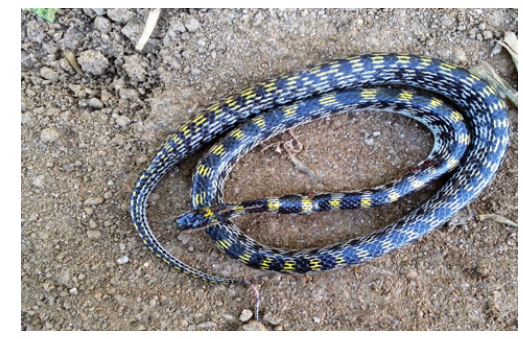

Himalayan Ratsnake, Elaphe hodgsoni (Günther 1860) (Colubridae) (Fig. 12) - We recorded this species from station 1 at an elevation of $1,754 \mathrm{~m}$ asl and an ambient temperature of $23^{\circ} \mathrm{C}$ in June 2015. Sahi (1979) listed the species from Kargil, Ladakh, and Srinagar.

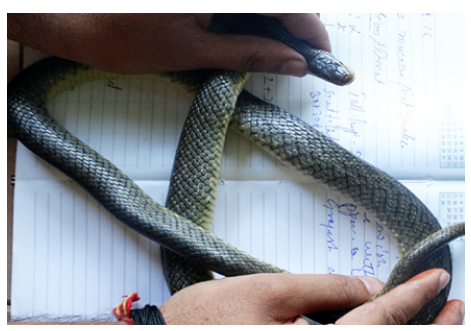

Braid Snake, Platyceps ladacensis (Anderson 1871) (Colubridae) (Fig. 13) - We recorded this species from station 1 at an elevation of 2,000 $\mathrm{m}$ asl and an ambient temperature of $22^{\circ} \mathrm{C}$ in March 2014. Uetz et al. (2018) noted that the distribution of this species includes Iran, Afghanistan, Turkmenistan, Uzbekistan, West Tajikistan, Pakistan, and India. This is a new record for the region; pattern and meristic characters match published descriptions of the species.

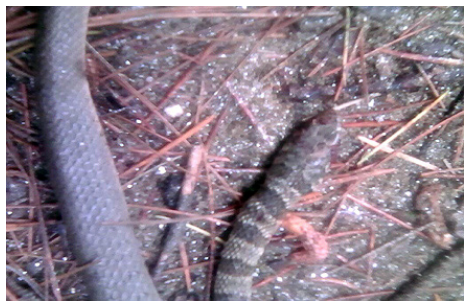

Common Cliff Racer, Platyceps cf. rhodorachis (Jan 1865) (Colubridae) (Fig. 14) - We recorded this species from station 2 at an elevation of 1,809 $\mathrm{m}$ asl and ambient temperatures of 21-22 ${ }^{\circ} \mathrm{C}$ in June 2014 and May 2015. Murthy and Sharma (1976, 1979) and Sahi (1979) reported the species from Khalsi (Ladakh) in June 1977. Khan and Khan (1996) reported it from Pakistan-occupied Kashmir.

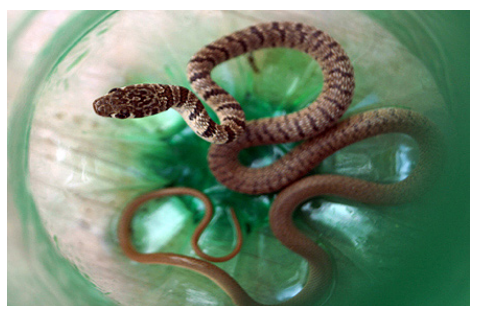

Glossy-bellied Racer, Platyceps ventromaculatus (Gray 1834) (Colubridae) (Fig. 15) - We recorded this species from station 1 in May 2014 and station 2 in April 2015 at elevations of 1,683-2,022 $\mathrm{m}$ asl and ambient temperatures of $23-25^{\circ} \mathrm{C}$. Sahi (1979) reported the presence of this species from Dachigaon (Srinagar) and Doda.

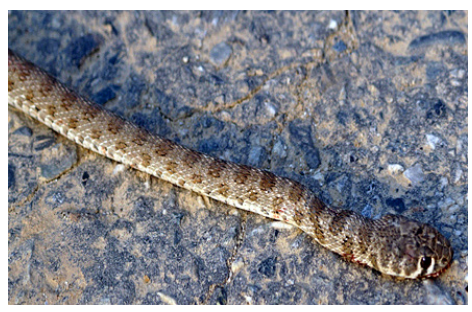

Indian Ratsnake, Ptyas mucosa (Linnaeus 1758) (Colubridae) (Fig. 16) - We recorded this species from stations 1, 2, 4, and 5 at elevations of 1,107-1,943 $\mathrm{m}$ asl and ambient temperatures of $15-28{ }^{\circ} \mathrm{C}$ in May and June 2014 and April and June 2015. All were near human settlements. Murthy and Sharma (1979)

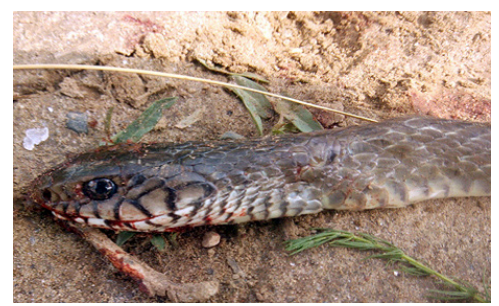


reported the species from the whole of Jammu and Kashmir. Sahi (1979) reported it from various parts of the state (viz., Gadigarh in December 1974, Kargil and Golgujral in May 1975, Bhaderwah in May 1976, Poonch in June 1976 and April 1977, Srinagar in May 1977), and Bahufort in June and August 1977). Khan and Khan (1996) reported the species from Pakistan-occupied Kashmir.

\section{Himalayan Pitviper, Gloydius himalayanus (Günther 1864)}

(Crotalidae) (Fig. 17) - We recorded this species from stations $1,3,4$, and 5 at elevations of 1,564-2,321 $\mathrm{m}$ asl and ambient temperatures of $15-30{ }^{\circ} \mathrm{C}$ in April to June 2014 and 2015 . Wall (1906) and Murthy and Sharma (1976) reported the species from Kashmir. Sahi (1979) recorded it from Bhaderwah in April 1977, from Kishtwar in May 1977 and from Pehalgam and Poonch in June 1977.

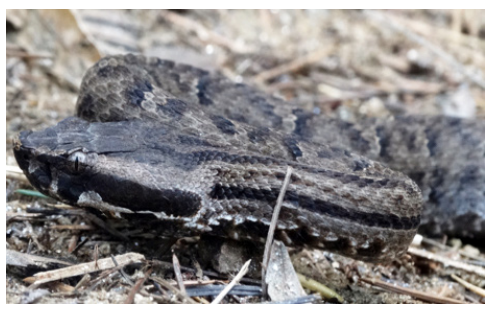

Blunt-nosed Viper, Macrovipera lebetina (Linnaeus 1758) (Viperidae) (Fig. 18) - We recorded this species from station 1 at an elevation of $2,029 \mathrm{~m}$ asl and an ambient temperature of 55 ${ }^{\circ} \mathrm{C}$ in April 2014. Wall (1906) reported the presence of M. lebetina

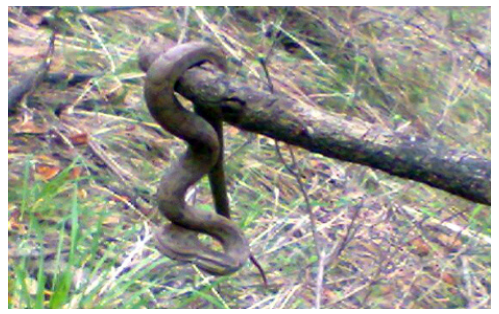

from Kashmir and Sahi (1979) reported a single individual from Sonamarg in June 1976.

The 17 species of reptiles we encountered from the Doda District compare poorly with the 65 species recorded by Sahi (1979) for all of Jammu and Kashmir. Three species (Calotes sp., Herpetoreas sieboldii, and Platyceps ladacensis) are reported herein for the first time in the Doda District and for the state. Six species (Calotes versicolor, Paralaudakia himalayana, Asymblepharus himalayanus, Herpetoreas platyceps, Elaphe hodgsoni, and Macrovipera lebetina have been reported from Jammu and Kashmir but had not been reported previously from the Doda District.

Three species (Asymblepharus himalayanus, Laudakia tuberculata, and Gloydius himalayanus) were observed frequently (20-30 times) and can be considered very common. These same three species were reported by Saikia et al. (2007) to be very commonly occurring species in temperate regions such as Himachal Pradesh. Seven species (Herpetoreas platyceps, Calotes versicolor, Cyrtodactylus himalayanus, Laudakia agrorensis, Lycodon mackinnoni, Platyceps cf. rhodorachis, and Ptyas mucosa were encountered 10-20 times and can be considered fairly common. Another seven species (Herpetoreas cf. sieboldii, Calotes sp., Elaphe hodgsoni, Paralaudakia himalayana, Platyceps cf. ladacensis, Platyceps ventromaculatus, and Macrovipera lebetina) were encountered only 1-10 times and can be considered rare.

We encountered no reptiles when the temperature was greater than $35^{\circ} \mathrm{C}$ or less than $10^{\circ} \mathrm{C}$. While we did note a gradual decrease in ambient temperatures as elevations increased, dense forest cover to about 2,000 $\mathrm{m}$ asl appears to reduce access to sunlight and moderate temperatures. At elevations above $2000 \mathrm{~m}$ asl, fully insolated basking sites were much more abundant, which was largely attributable to a more open forest canopy and a greater number of gaps in the forest.

Some of the snakes encountered during the present study were larger than those Sahi (1979) had recorded in the same general area (Table 1). Although sample sizes are small and the differences might be coincidental, anthropogenic changes to habitats (abundance of refuse and enhanced productivity in agricultural areas) in the intervening years might have increased prey availability for these species.

Table 1. Comparison of sizes of some species of snakes encountered during the present investigation with those recorded by Sahi (1979). All measurements are in $\mathrm{mm}$. SVL = snout-to-vent length; $\mathrm{TL}=$ tail length.

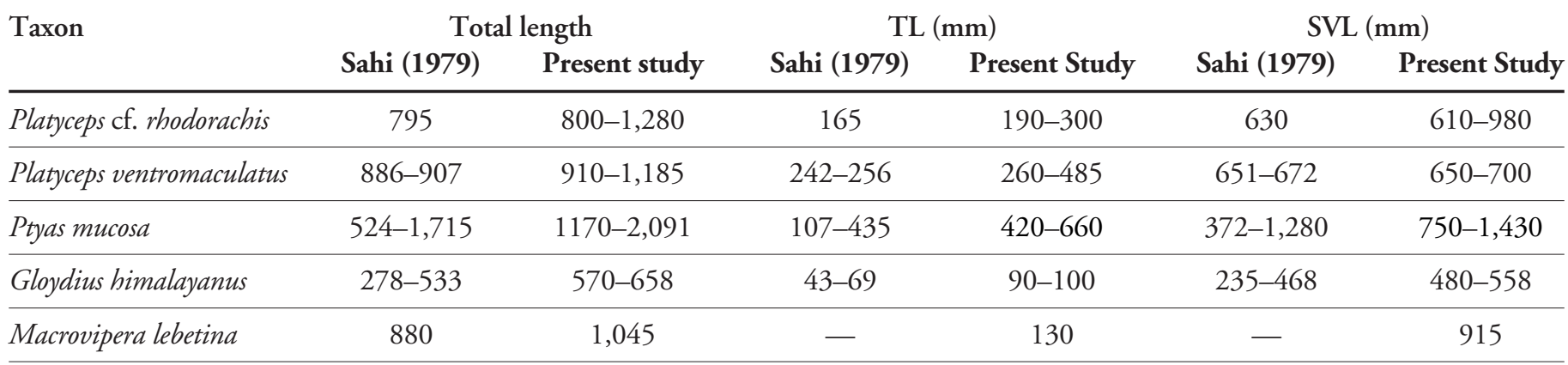


Many of the species we recorded are potentially threatened by changing land-use patterns. Residential and agricultural development of previously natural systems has led to substantial losses in reptilian habitat. In addition, destruction and modifications of egg-laying microhabitats probably have aggravated the situation. In addition, road mortality has become a major threat to many snakes (e.g., Bonnet et al. 1999; Vitt and Caldwell 2013), particularly during breeding seasons when males range widely in search of mates and when females disperse to ovipositioning sites. Indiscriminate killing of reptiles primarily attributable to fear (e.g., Nath et al. 2011) also takes a major toll.

\section{Literature Cited}

Aengals, R., S.V.M. Kumar, and M.J. Palot. 2012. Updated Checklist of Indian Reptiles. (http://www.lacertilia.de/AS/Bibliografie/BIB_6715.pdf).

Agarwal, I., V.K. Mistry, and R. Atreya. 2010. A preliminary checklist of reptiles of Eaglenest Wildlife Sanctuary, West Kameng District, Arunachal Pradesh, India. Russian Journal of Herpetology 17: 81-83.

Ali, G., M. Kak, M. Kumar, K.S. Bali, I.S. Tak, G. Hassan, and B.M. Wadhwa. 2004. Acute renal failure following Echis carinatus (Saw-scaled Viper) envenomation. Indian Journal of Nephrology 14: 177-181.

Bonnet, X., G. Naulleau, and R. Shine. 1999. The dangers of leaving home: Dispersal and mortality in snakes. Biological Conservation 89: 39-50.

Campbell, H.W. and S.P. Christman. 1982. Field techniques for herpetofaunal community analysis, pp. 193-200. In: N.J. Scott, Jr. (ed.), Herpetological Communities. Wildlife Research Report No. 13. U.S. Fish and Wildlife Service, Washington, U.S.

Chowdhary, N. 2010. Diversity and Status of Wildlife Fauna of District Rajouri, J\&K State). Unpublished Ph.D. Thesis, University of Jammu, Jammu, Jammu and Kashmir, India.

Daniel, J.C. 2002. The Book of Indian Reptiles and Amphibians. Bombay Natural History Society, Mumbai, India.

Das, S.M. 1966. Palearctic elements in the fauna of Kashmir. Nature 212: 1320 1330.

Duda, P.L. and D.N. Sahi. 1977. An uptodate checklist of herptiles of Jammu and Kashmir. Jammu and Kashmir University Review 6(10): 1-7.

Duda, P.L. and D.N. Sahi. 1978. Cyrtodactylus himalayanus: A new gekkonid species from Jammu, India. Journal of Herpetology 12: 351-354.

Fenton, L.L. 1910. The Snakes of Kashmir. Journal of the Bombay Natural History Society 29: 1002-1004.

Gibbons, J.W., D.E. Scott, T.J. Ryan, K.A. Buhlmann, T.D. Tuberville, B.S. Metts, J.L. Greene, T. Mills, Y. Leiden, S. Poppy, and C.T. Winne. 2000. The global decline of reptiles, déjà vu Amphibians. Bioscience 50: 653-666.

IUCN (International Union for Conservation of Nature). 2018. The IUCN Red List of Threatened Species. Version 2018-1 (http://www.iucnredlist.org/).

Khaire, N.K. 2010. Snakes. Jyotsna Prakashan, Dhavalgiri, Pune, Maharashtra, India.

Khaire, N.K. 2014. Indian Snakes: A Field Guide. Jyotsna Prakashan, Dhavalgiri, Pune, Maharashtra, India.

Khan, A.Q. and M.S. Khan. 1996. Snakes of state of Azad Jammu and Kashmir. Proceedings of Pakistan Congress of Zoology 16: 173-182.

Khan, M.S. and T.J. Papenfuss. 2016. Herpetoreas sieboldii. The IUCN Red List of Threatened Species 2016: e.T176337A96266746 (http://dx.doi.
org/10.2305/IUCN.UK.2016-1.RLTS. T176337A96266746.en).

Manhas, A., N.R.R. Wanganeo, and A. Wanganeo. 2015. First record of Himalayan Wolf Snake (Lycodon mackinnoni Wall, 1906) in Doda district of lower Himalayas, Jammu and Kashmir, India. World Research Journal Biology of Biological Sciences 1: 2-4.

Manhas, A., R. Raina, and A. Wanganeo. 2016. An assessment of reptilian diversity and their distribution in Jammu and Kashmir state from Jammu City in northern India: A case study. International Journal of Fauna and Biological Studies 3(3): 20-23.

Manhas, A., R. Raina, and A. Wanganeo. 2018a. Observations of Agror Agamas, Laudakia agrorenisis (Stoliczka, 1872) (Sauria: Agamidae) in the Doda District, Jammu and Kashmir, India. Reptiles and Amphibians 25: 52-54.

Manhas, A., R. Raina, and A. Wanganeo. 2018b. Range extension of Cyrtopodion himalayanus Duda and Sahi, 1978 (Reptilia: Sauria) in Jammu Province of State Jammu and Kashmir from District Doda, Northern India. Amphibian \& Reptile Conservation 12: 48-51.

Murthy, T.S.N. and B.D. Sharma. 1976. A contribution to the herpetology of Jammu and Kashmir. British Journal of Herpetology 5: 533-538.

Murthy, T.S.N. and B.D. Sharma. 1979. Second report on the herpetofauna of Jammu and Kashmir. The Snake 11: 234-241.

Nath, A., H. Singha, and A. Das. 2011. Snakes of Bongaigaon Municipality Area, Assam, India. Reptile Rap 13: 9-13.

Sahi, D.N. 1979. A Contribution to the Herpetology of Jammu and Kashmir. Unpublished Ph.D. Thesis, University of Jammu, Jammu, Jammu and Kashmir, India.

Sahi, D.N. and P.L. Duda. 1982. Notes on little known lizards from Jammu and Kashmir State. Journal of the Bombay Natural History Society 80: 227-229.

Sahi, D.N. and P.L. Duda. 1985. A checklist and keys to the amphibians and reptiles of Jammu and Kashmir State, India. Bulletin of the Chicago Herpetological Society 20: 86-97.

Sahi, D.N. and P.L. Duda. 1986. Affinities and distribution of amphibians and reptiles of Jammu and Kashmir State (India). Bulletin of the Chicago Herpetological Society 21: 84-88.

Saikia, U., D.K. Sharma, and R.M. Sharma. 2007. Checklist of the reptilian fauna of Himachal Pradesh. Reptile Rap 8: 6-9.

Sharma, B.D. and T. Sharma. 1975. Some new records of snakes (Reptilia: Serpentes) from Jammu and Kashmir State. Current Science 44: 646-647.

Sharma, O.P. and G. Kour. 2005. Karyology of four Indian snakes. Caryologia 58: 380-386.

Smith, M.A. 1935. The Fauna of British India, Ceylon and Burma, Including the Whole of the Indo-Chinese Sub-region. Reptilia and Amphibia. Vol. III.-Sauria. Taylor and Francis, London,UK.

Smith, M.A. 1943. The Fauna of British India, Ceylon and Burma, Including the Whole of the Indo-Chinese Sub-region. Reptilia and Amphibia. Vol. III.Serpentes. Taylor and Francis, London,UK.

Uetz, P., P. Freed, and J. Hošek (eds.). 2018. The Reptile Database (http://www. reptile-database.org).

Verma, A. K. and D.N. Sahi. 1995. On the distribution, ecology and status of the Indian Monitor Lizard Varanus bengalensis in J\&K State. Cobra 19: 6-9.

Vitt, L.J. and J.P. Caldwell. 2013. Herpetology: An introductory Biology of Amphibians and Reptiles. 4th ed. Elsevier Inc., Oxford, UK.

Wall, F. 1906. A new Himalayan snake (Lycodon mackinnoni). Journal of the Bombay Natural History Society 17: 29-30.

Whitaker, R. 2006. Common Indian Snakes: A Field Guide. 2nd ed. Macmillan Publishers, Chennai, India.

Whitaker R. and A. Captain. 2004. Snakes of India: The Field Guide. Draco Books, Chennai, India. 